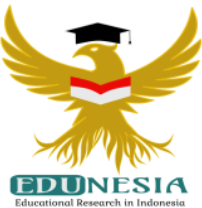

\title{
The Development Design of Group Counseling with Behavioral Contract Technique to Reduce Students' Academic Procrastination Behavior
}

\author{
Alfiani Fernita Sari ${ }^{1}$; Yulia Ayriza ${ }^{2}$ \\ 1,2Graduate School of Guidance and Counseling, Yogyakarta State University, Indonesia \\ ${ }^{1}$ Corresponding Email: alfiani9294@gmail.com, Phone Number : 0821 xxxx xxxx
}

\begin{abstract}
Article History:
Received: Nov 29, 2020

Revised: Dec 04, 2020

Accepted: Dec 08, 2020

Published: Jan 01, 2021
\end{abstract}

Keywords:

group counseling,

behavioral contract, procrastination.

Kata kunci:

Konseling kelompok behavioral contract, prokrastinasi.

How to cite:

Sari, A.F., \& Ayriza, Y. (2021). The Development Design of Group Counseling with Behavioral Contract Technique to Reduce Students' Academic Procrastination Behavior. Edunesia: Jurnal Ilmiah Pendidikan, 2 (1): 189-199.

This is an open access article under the CC-BY-NC-ND license cc) $(\$)$
Abstract: There are varoius techniques in the counseling approach which are implemented according to the counselee's problem. One of the popular counseling techniques in the behavioral approach is called the behavioral contract. The purpose of this study was to develop a group counseling stage design of the behavioral contract technique to solve the student's academic procrastination problem. Development of the group counseling stage design of the behavioral contract technique used the Borg and Gall development model. The development of the design consist of three stages which begins with the need asessment stage, the product development planning stage, and the initial product development stage. The data collection technique was conducted by interviewing 5 counseling teachers from different schools. Product validation was carried out with expert counseling expert judgment with 3 revisions. The result was the design of the behavioral contract technique group counseling stage can be applied in counseling service in schools that was consisting of 3 stages, namely: the beginning stage, the working stage, and the terminating stage. Each stage of the group counseling contains activity steps that should be done. Design of group counseling with behavioral contract technique is compiled for 8 meetings with a duration of 45 minutes per meeting. This research is only up to the third stages, namely developing the initial product. Therefore, the next step in this research will be further developed and published in another article.

\begin{abstract}
Abstrak: Teknik dalam pendekatan konseling sangat bermacam-macam yang dapat digunakan sesuai dengan masalah konseli. Salah satu teknik konseling dalam pendekatan behavior yaitu teknik behavioral contract. Tujuan penelitian ini adalah mengembangkan rancangan tahapan konseling kelompok teknik behavioral contract untuk mengatasi masalah prokrastinasi akademik siswa. Pengembangan rancangan konseling kelompok teknik behavioral contract menggunakan model pengembangan Borg and Gall. Pengembangan produk rancangan ini terdiri dari 3 tahapan, diawali dari tahap asesmen kebutuhan, tahap perencanaan mengembangkan produk, dan tahap mengembangkan produk awal. Teknik pengumpulan data dilakukan dengan wawancara kepada 5 orang guru bimbingan konseling yang berbeda sekolah. Validasi produk dilakukan dengan expert judgement ahli konseling sebanyak 3 kali revisi. Hasilnya adalah rancangan tahapan konseling kelompok dengan teknik behavioral contract dapat diaplikasikan dalam layanan konseling di sekolah yang terdiri dari 3 stage/tahap, yaitu: beginning stage, working stage, dan terminating stage. Setiap tahapan konseling kelompok terdapat langkah-langkah kegiatan yang harus diselesaikan. Rancangan tahapan konseling kelompok teknik behavioral contract disusun untuk 8 pertemuan dengan durasi watu 45 menit setiap pertemuan. Penelitian ini hanya sampai tahap ketiga yaitu mengembangkan produk awal. Oleh karena itu langkah berikutnya pada penelitian ini akan dikembangkan lebih lanjut dan dipublikasikan pada artikel lain.
\end{abstract}




\section{A. Introduction}

Guidance and counseling services have been a crucial component in the school's teaching system in order to facilitate students to achieve optimal progress based on their development stages. Kartadinata (2011) explains that guidance is to facilitate students (counselees) in developing healthy behaviors, and effective environments to support their development, while counseling is an assistance technique that directly helps students to overcome their problems and decision making. During this service, the guidance and counseling teachers can apply a variety of counseling approaches, in the group or individual. In the group counseling setting, the technique of behavioral contract can be applied. According to Gibson and Mitchell (2011), the behavioral approach views behavior as a result of responses learned from experiences and events in one's life. Similarly, Corey (2013) explains that the behavioral approach focuses on behaviors and transformational learning experiences that can be directly observed.

According to Corey (2012), school counseling services are implemented referring to topics or problems that occur among students. Group counseling as a means of repairing and preventing students' problems through mutual support or empathy from the counselor and each group member or student involved in group counseling. The goal is that group members can learn new skills for decision making and problem solving to be applied in the future. Carrying out group counseling needs to be done through clear and structured stages of how and what the counselor needs to convey at each stage and each group counseling session. Corey (2012) identifies the stages of group counseling into the group formation, the initial stage, the transition stage, the work stage, the consolidation stage, the evaluation or the follow-up stage. Meanwhile, the stages of group counseling by Jacobs et al (2012) include the beginning stage, working stage, and terminating or closing stage.

However, various research journals show that the stages of group counseling, especially with behavioral contract techniques, have not been designed based on the existing theories. Shek and Leung (2013) create the stages of peer group counseling for teens who have internet addiction behaviour covering 6 sessions in group counseling, namely the first session (introducting among group members, creating group norms, sharing expectations for behavioral change), the second and third sessions (building groups and recognizing each other's strengths by completing tasks given from the group leader), the forth and fifth sessions (self exploration, and group sharing), and the sixth session (providing mutual support and feedback for group experience). Another case, Boonsuchat (2015) applies group counseling to counselees who experience anxiety covering the first session with relationships building, the second session with "Happy House", the third session with "Collaborative Constructing" (Appropriate World for our beloved persons), the forth session "Sustainable Happiness" activities, and the fifth session as the end of the group counseling. The stages of group counseling developed by Bonsuuchat have not been conveyed specifically, only writing down important points that are done in each session. In contrast to the above research findings that describe the design stages of group counseling, a study conducted by Ningsih, Supriyo, and Mugiarso (2016) implements the behavioral contract technique in individual counseling settings to overcome low students' learning independence and its implementation stages that covers the first stage of relationships building with counselee; the second stage of the problems disclosure experienced by the counselee, the third stage of the counseling objectives setting, the fourth stage of the behavioral contract application; the fifth stage of evaluation.

The counseling services must be related to students who experience problems. Abdullah (2017) based on the results of his research shows the most common negative behaviors that occur in schools, such as disobedience to teachers, underachievement, 
assignments postponement, absenteeism, aggressive towards peers or teachers, loneliness, anxiety, shame, anger, and disability. The student responsibility is not only studying, doing schoolwork, and participating in academic processes but also non-academic activities at school. As school students, they often get a lot of homework, especially if all subject teachers give homeworks once a week and require them to complete it on time. However, many students are not responsible to complete their assignments punctually and they find it difficult to manage their time between learning and playing where it can lead to academic procrastination. Muramatsu et al (2011) state that academic procrastination is the students' behaviour to postpone the completion of their tasks. As a result, when it gets closer to the deadline, they can not present the optimal results of their assignments. In line with this, Akhtar et al (2017) emphasize that locus of control, time and learning management positively affect student academic achievement in which they believe in their own abilities and efforts. If students have good time management, they can effectively set goals and try to achieve it by controlling their learning environment. On the other hand, Aydogan and Akbarov (2018) classify individuals who cannot schedule tasks and manage their time well to complete their tasks as procrastinators. According to Kljajic and Gaudreau (2018), due to the limited time, even the punctual students will also postpone their school work because they have plentiful organizational activities.

Quantitatively, the level of student academic procrastination can be categorized as high. Azure (2011) explains that academic procrastination that occurs in students is around $40 \%$ to $60 \%$ always procrastinating writing papers, delaying studying during exams, and reading assignments every week. The academic procrastination behavior has also become a common issue among students in Indonesia, it can be seen based on the research results in several cities of Indonesia. Utaminingsih and Setyabudi (2012) examine the academic procrastination of high school students in Tangerang with $56.30 \%$ of students who show moderate academic procrastination, and $43.70 \%$ of students who get high academic procrastination. It is similar to Munawaroh et al (2017) research that the level of academic procrastination among students in one private junior high school in Yogyakarta in the high level is $17.2 \%$, the moderate level is $77.1 \%$, and the low level is $5,7 \%$. Moreover, Saputra (2017) finds that that academic procrastination among vocational students in Ngawi is $16 \%$ for low academic procrastination, $57 \%$ for moderate, and $27 \%$ for high academic procrastination.

Having those facts on the level of academic procrastination, it seems that behavioral contract counseling service can be an appropriate service model to be proposed, both in group and individual settings. However, there has not been found the design of the counseling group with the behavioral contract technique as the guide to its implementation. The prelimenary study was also done by interviewing the guidance and counseling teachers in junior high schools in which they admitted that they never made a stage design or even conduct the group counseling of behavioral contracts. In fact, Goroshit (2018) explains that academic procrastination can hamper student academic performance so prevention steps must be taken. It is necessary to design the implementation stages of the treatment so that the desired goals can be achieved. Thus, this research aimed at producing the design stage for the group counselling with behavioral contract techniques which can be applied by the guidance and counseling teachers in order to overcome the students' academic procrastination.

\section{B. Method}

This research employed Research and Development (R\&D) by using Borg and Gall development model (Sugiyono, 2015) consisting of the following procedures: 1) the needs 
assessment, 2) the planning, 3)the initial products development, 4) initial field testing, 5) the main product revision, 6) the major field test, 7) the product revision, 8) the operational field test, 9) the final product revision, 10) the product implementatiom. The first procedure was a needs assessment through interviews of the guidance and counseling teachers. The interview result showed that there were no guidance and counseling teachers who designed group counseling with behavioral contracts. The second procedure was planning the product development in the form of the stages of the counseling group with behavioral contract techniques. At this planning stage, the researchers gathered the material for product development from books and journals (literature studies) about group counseling and behavior contract techniques. The third procedure was developing a product design of the group counseling with behavioral contract technique. It was done as the procedure of the initial product development and it was validated by a counselor validator. The product validation was done qualitatively with three revision processes.

\section{Result and Discussions}

\section{Result}

In developing this product in the form of the design stage of the conseling group with behavioral contract techniques, there were procedures that had been done in this study based on the theories of Borg and Gall. The draft of the behavioral contract technique had been developed until the third stage, i.e the initial product development that already been validated through several stages as follows.

\section{Beginning Stage}

a. First meeting

1) The counselors began the group counseling activities with greetings.

2) The counselor and group members introduced themselves to one another.

3) The counselors raised awareness that the presence of counselees was very important in this counseling session. The counselor asked group members regarding a) the feelings and thoughts of the counselee when the counselor invites the counselee in group counseling, $b$ ) the reasons why the counselor invited group members to come to the group counseling session, then the counselor conveyed the reasonable facts. The question was asked by the counselor because the counselor invited the counselee based on the pretest score on the academic procrastination scale. However, to make the counselee aware, the counselor made the announcement (pamphlet) which contained the theme of the group counseling, the description of the group counseling theme, and the time for group counseling.

4) Each group member told what happened to himself related to postponement behavior.

5) The counselor asked their wants or needs among the members of this group counseling.

6) The counselor explored their expectations and goals to be achieved during group counseling activities.

7) The counselor leaded group members to discuss the rules that must be obeyed in group counseling.

8) The counselors and group members helped each other to create mutual trust, and openness related to academic procrastination. This openness aspect between counselors and fellow group members was very important at this stage so that there were no obstacles in the next counseling process. As stated by Moran (Gladding, 2012 , p. 316) that the counselors in the initial group sessions often used self- 
disclosure for group members to improve the processes, for example, the counselor revealed himself related to the topic or problem being discussed.

9) After group members were getting acquainted with each other, the trust can grow. Then, there was no worry about carrying out group counseling activities. The counselor asked the readiness of all group members to proceed to the second stage. When all group members were ready and agreed to the second stage, it was followed by the second stage of the counseling session, namely the working stage.

\section{Working Stage}

a. Second Meeting

1) The counselors started group counseling activities with greetings.

2) The counselor asked each group member the core problem of academic procrastination behavior that had been discussed at the previous meeting.

3) The counselor and group members determined whose problems will be discussed first.

4) When one group member was expressing his problem, the counselor and other group members listened and actively asked their problem to be explored deeply.

5) The counselor gave reinforcement to the counselee on their thoughts, feelings, and behavior.

6) Before concluding the counseling session, the counselor summarized what had been discussed to give reinforcements to all group members and asked again what each group member wanted to do after this meeting.

7) The counselors end entire group counseling ended the session with prayer and greetings.

b. Third Meeting

1) The counselors began group counseling activities by greetings the students.

2) The counselor gave questions to the group members about the problems that had been revealed.

3) It was followed by revealing the problem from other group members and the counselor also asked other group members to listen and actively provided questions so that the problem can be explored comprehensively.

4) The counselor gave reinforcements on thoughts, feelings, and behavior to the counselee.

5) The class session was over, while there were still problems from the group members that had not been discussed yet, so the meeting proceeded to the next meeting.

6) Before concluding the counseling session, the counselor summarized what had been discussed to give reinforcements to all group members and asked again what each group member wanted to do after this meeting.

7) The counselors ended group counseling by having prayer.

c. Forth meeting

1) The counselors began group counseling activities by having greetings.

2) The counselors gave questions to the group members about the problems that had been revealed.

3) It was followed by revealing the problem from other group members and the counselor also asked other group members to listen and actively provided questions so that the problem can be explored comprehensively. 
4) After group members had revealed their problems, the counselors explained to the group members about the behavioral contract.

5) The counselor requested all group members to make a written agreement related to their problem of academic procrastination. This written agreement was drawn up with the counselor and counselee. The contract format was presented below:

Behavioral Contract
Name, ................. (conselee name), agreed to complete the assignments or
homeworks start from... until....
Subsequently, I will show my homeworks to........... (counselor) on the date... to be
documented that I had done my homeworks.
If I do not bring my homeworks to the counselor at the scheduled meeting, I am ready
to accept all consequences.....
Signed:
Conselee
(Studnets' Name) Counselor

Figure 1. The Format of the Behavioral Contract

6) The counselor reviewed and summarized what had been done in this meeting and conveyed what would be done at the next meeting.

7) The counselors ended group counseling with prayer and greetings.

d. Fifth Meeting

1) The counselors started group counseling activities with greetings.

2) The counselor reviewed the activities of the previous meeting.

3) After the group members had designed their behavioral contract, each group member read the behavioral contract to be performed.

4) All group members have the same time on their behavioral contract, the date to start the assignment and the deadline to collect the assignment to the counselor.

5) The counselors provided self-observation sheets to each group member to be filled in accordance with what had been done.

6) After all group members make their behavioral contract, the counselor reviewed and summarized based on what had planned at this meeting.

7) The counselor ended the group counseling session with prayer.

e. Sixth meeting

1) The counselors started group counseling activities with greetings.

2) The counselor asked the counselee one by one to show their tasks that had been completed to check whether the behavior to complete the task before the deadline can be learned as written in the behavioral contract.

3) When there were counselees who had not consistently run the behavioral contract, the counselor provided the consequences to the counselee based on the behavioral contract.

4) The counselors provided reinforcements to the counselee in the form of praise and gifts. The procedures or the ways to provide reinforcements to the counselee can be through contingency groups (Sarafino, 2012). It was done by giving reinforcements that depend on the performances of all group members. The types of contingency group structures are: 
1.1 Reinforcements were given to the group members who had fulfilled the behavioural contract (Independent group contingency).

1.2 Reinforcements were given to one or several members who had fulfilled the behavioural contract (Dependent group contingency)

1.3 Reinforcements were given to all group members that had been consistently performed the behavioral contract (interdependent group contingency).

5) The counselors provided feedbacks to the counselee.

6) The counselors reviewed and summarized the activities of this session.

7) The counselor ended the group counseling session with prayer.

f. Seventh meeting

1) The counselors started the group counselling activities with greetings.

2) The counselor asked the counselee one by one to show their tasks that had been completed to check whether the behavior to complete the task before the deadline had been learned as written in the behavioral contract.

3) When there were counselees who were not consistently run the behavioral contract, the counselors provided some consequences since they had agreed in the behavioral contract.

4) The counselors provided reinforcements to the counselee in the form of praise and gifts.

5) The counselors provided feedback to the counselee.

6) The counselor ended the group counseling with prayer and greetings.

\section{Terminating stage}

a. Eighth Meeting

1) The counselors started group counseling activities with greetings.

2) The counselor and the group members had mutual sharing about the previous activities. The group members shared their experiences on how to carry out the behavioral contract, whether the new behavior was achieved or not, the benefits of the counseling session, and the obstacles in performing the behavioral contract.

3) The counselors provided feedback on counseling activities.

4) The counselors and the group members expressed their impressions during the counseling sessions, and their expectations.

5) The counselors gave praise to the group members.

6) The counselor offers to the group whether this kind of session needs to continue or not.

7) The counselor ended the counseling meeting.

\section{Discussions}

The design stages that have been described above are intended for guidance and counseling teachers as a guide for implementing group counseling. The guidance and counseling teachers in group counseling can act as group leaders who become facilitators for group members. Corey (2012) explains that the role of group leaders is to build group interaction, to help each group member in setting the goals, and to encourage the group members to make plans and actions to change their behavior in the future. Harel et al (2012) state that groups counseling support new behaviors, exchange positive thoughts and feelings as well as give positive feedback to one another. In line with this, Jacobs et al (2012) urge that group counseling enables each member to learn more about listening to others 
than talking. Each group member can also receive a lot of positive feedbacks from other group members.

The design stages of the group counseling that have been described above referring to the theory from Jacobs et al (2012) in which the stages of group counseling are beginning stage, working stage, and terminating or closing stage. The beginning stage or initial stage is the initial stage of group counseling where in the counselor and group members get to know each other to build trust, comfort, group dynamics, self-disclosure in order to gain the problems experienced by the group members, as well as create rules that must be adhered during the group counseling sessions. The working stage refers to the stage where group members begin to express the problems experienced by each group member. Here, the counselors pay attention to all group members and their attitudes and interactions from each group member. The terminating stage is the closing stage where the group members have learned new behaviors of which the purpose of the behavior change has been fulfilled. At this stage, the group members express messages and impressions during group counseling. It is supported by Miltenberger (2012) by defining behavioral contracts as a written agreement between two people (counselor and counselee) which contains the target of new behavior that must be performed by the counselee. The existence of this group counseling is to support one other, exchange ideas, and provide positive suggestions for each group member to learn new behaviors. Furthermore, Dubois et al (2017) mentions that group members can also inspire to follow the behavior of their peers (role models) who are successfully practiced new behaviors.

Meanwhile, Miltenberger (2012) propose 5 components that must be included in behavior contract, i.e. identifying the target behavior (behavior to be improved or derived), stating the way of the behavior measurements (observation, documentation, or behavior product), deciding the period of the session (start date and end date), determining the reinforcements and punishments, deciding the parties involved in the behavior contract. Sarafino (2012) reveals the benefit of the behavioral contract is that the involved parties will be consistent in carrying out their specified targets, respective roles, goals, as well as in improving communication among the involved parties. As noted above, counselors and counselees make an agreement on the behavior to be changed, namely academic procrastination.

The behavioral contract technique guides students to consistently perform new behaviors, i.e. completing tasks punctually. This technique is expected to be able to overcome academic procrastination behavior since it will negatively affect student achievement. As explained by Rabin et al (2011) that the consequences of academic procrastination behavior can decrease students' academic outcomes. Grunschel et al (2012) also utter that, actually, students realize academic procrastination will put them under pressure and regret. Balkis et al (2013) agree that irrational thinking about academic assignments makes students behave procrastinating and it really affects their academic achievement. So, it will be so useful that the guidance and counseling teachers can design the implementation of counseling activities as a responsive service to solve this kind of problem. Similarly, Teodora and Langa (2019)believes that counseling services can develop 
students' knowledge because the guidance and counseling teachers can arrange structured treatments or interventions.

This study is limited to the design of the behavioral contract technique among students as the counseling targets in the guidance and counseling service at schools and it has not reached the phase of product trial yet.

\section{Conclusion}

The design stages of group counseling are developed by following the product development procedures based on Borg and Gall. The procedure for developing group counseling with the behavioral contract has been through expert validation. The stages of group counseling are designed for 8 meetings. The group counseling consisting of three stages, namely the beginning stage, the working stage, and the terminating stage. The beginning stage contains the stage where group members and group counselor leaders begin to know each other, build trust and self-disclosure, was well as make norms duirng the group counseling. The working stage refers to the stage where all group members express their problems and it is followed by the counselor who applies the behavioral contract techniques, directs each counselee to design behavioral targets, and decides consequences in the behavioral contract so that the counselee can consistently perform the contract. The terminating stage is the stage for the counselor to end the counseling process. Here, the counselor provides feedback, while the group members express the impressions and feedbacks during group counseling. The group members also perform their behavioral changes during counseling and beyond the counseling session. This research only covered the third stage in which the next step will be further developed and published in another article.

\section{Acknowledgment}

In completing this article, the author has been guided by lecturers, so the suggestions and criticisms from the lecturers were very constructive during the writing of this article.

\section{References}

Abdullah, M. Q. (2017). Psychosocial problems of schoolchildren and the psychological counseling approaches implicated by counselors for treating it. COUNS-EDU: The International Journal of Counseling and Education, 2(4), 150-159. https://doi.org/10.23916/0020170212940

Akhtar, S. N., Iqbal, M., \& Tatlah, I. A. (2017). Relationship between Intrinsic Motivation and Students' Academic Achievement: A Secondary Level Evidence. Bulletin of Education and Research, 39(2), 19-29.

Aydoğan, H., \& Akbarov, A. (2018). A Case Study on Academic Procrastination in EFL Settings in Turkey. Acta Didactica Napocensia, 11(3-4), 79-88. https://doi.org/10.24193/adn.11.3-4.6

Azure, J. A. (2011). Correlates of course anxiety and academic procrastination in higher education. Global Journal of Educational Research, 10(1), 55-65. 
Balkis, M., Duru, E., \& Bulus, M. (2013). Analysis of the relation between academic procrastination, academic rational/irrational beliefs, time preferences to study for exams, and academic achievement: A structural model. European Journal of Psychology of Education, 28(3), 825-839. https:/ / doi.org/10.1007/s10212-012-0142-5

Boonsuchat, J. (2015). Group Counseling for Reducing the Anxiety in Parents of Children with Autism. Procedia - Social and Behavioral Sciences, 197(February), 640-644. https://doi.org/10.1016/j.sbspro.2015.07.051

Corey, G. (2012). Theory \& Practice of Group Counseling (8th ed.). USA: Brooks/Cole, Cengage Learning.

Corey, G. (2013). Theory and practice of counseling and psychotherapy (9th ed.). USA: Brooks/Cole, Cengage Learning.

Dubois, J. M. B., Struzziero, J., Briesch, A. M., Hoffman, J. A., \& Toback, R. (2017). Implementing self-management within a group counseling context: Effects on academic enabling behaviors. Psychology in the Schools, 1-16. https://doi.org/10.1002/ pits.22029

Gibson, R. (2011). Bimbingan dan konseling edisi ketujuh (Terjemahan Yudi Santoso). Yogyakarta: Pustaka Pelajar (Edisi asli diterbitkan tahun 2008 oleh Pearson Education Inc. Upper Saddle River New Jersey).

Gladding, S. T. (2012). Konseling: Profesi yang menyeluruh edisi keenam. (Terjemahan Winarno dan Lilian Yuwono). Jakarta: Indeks.

Goroshit, M. (2018). Academic procrastination and academic performance: An initial basis for intervention. Journal of Prevention and Intervention in the Community, 46(2). https://doi.org/10.1080/10852352.2016.1198157

Grunschel, C., Patrzek, J., \& Fries, S. (2012). Exploring reasons and consequences of academic procrastination: an interview study. . European Journal of Psychology of Education, 28(3), 841-861.

Harel, Y., Shechtman, Z., \& Cutrona, C. (2012). Exploration of Support Behavior in Counseling Groups With Counseling Trainees. Journal for Specialists in Group Work, 37(3), 202-217. https:// doi.org/10.1080/01933922.2011.646087

Jacobs, E. D. E., Masson, R. L., \& Harvill, R. L. (2012). Group Counseling Strategies and Skills (7th ed.). USA: Brooks/Cole, Cengage Learning.

Kartadinata, S. (2011). Menguak Tabir Bimbingan dan Konseling sebagai Upaya Pedagogis. Bandung: UPI Press.

Kljajic, K., \& Gaudreau, P. (2018). Does it matter if students procrastinate more in some courses than in others? A multilevel perspective on procrastination and academic achievement. Learning and Instruction, 58(February), 193-200. https://doi.org/10.1016/j.learninstruc.2018.06.005 
Miltenberger, R. G. (2012). Behavior Modification: Principles and Procedures, Fifth Edition. In Behavior modification: Principles and procedures (2nd ed.). (5th ed.). https://doi.org/10.1080/01431161.2016.1204478

Munawaroh, M., Alhadi, S., \& Saputra, W. (2017). Tingkat Prokrastinasi Akademik Siswa Sekolah Menengah Pertama Muhammadiyah 9 Yogyakarta. Jurnal Kajian Bimbingan Dan Konseling, 2(1), 26-31. https://doi.org/10.17977/um001v2i12017p026

Muramatsu, K., Kunimune, H., \& Niimura, M. (2011). An analysis for the causes of the academic procrastination behaviour. Lecture Notes in Computer Science (Including Subseries Lecture Notes in Artificial Intelligence and Lecture Notes in Bioinformatics), 6883 LNAI(PART 3), 529-538. https://doi.org/10.1007/978-3-642-23854-3_56

Ningsih, C. (2016). Konseling individual pendekatan behavioral teknik behavior contract dalam mengatasi rendahnya kemandirian belajar. Indonesian Journal of Guidance and Counseling: Theory and Application, 5(3), 19-23. Retrieved from http//:journal.unnes.ac.id/sju/index.php/jbk

Rabin, L. A., Fogel, J., \& Nutter-Upham, K. E. (2011). Academic procrastination in college students: The role of self-reported executive function. Journal of Clinical and Experimental Neuropsychology, 33(3), 344-357. https://doi.org/10.1080/13803395.2010.518597

Saputra, W. N. E. (2017). Effectiveness of cognitive restructuring technique to reduce academic pracrastination of vocational high school students. COUNS-EDU: The International Journal of Counseling and Education, 2(1), 6. https://doi.org/10.23916/002017025510

Sarafino, E. P. (2012). Applied Behavior Analysis: Principles and Procedures in Behavior Modification. https://doi.org/10.1177/1069072715621532

Shek, Daniel T L, PhD, FHKPS, BBS, JP; Leung, H. (2013). Development of an integrated intervention model for Internet addiction in Hong Kong. International Journal of Child and Adolescent Health; Hauppauge, 6(4), 475-486.

Sugiyono. (2015). Metode Penelitian dan Pengembangan (Research and Development). Bandung: Alfabeta.

Teodora, T, \& Langa, C. (2019). Influencing students ' attitudes towards school counseling. Journal of Education Sciences \& Psychology, IX(2), 129-135.

Utaminingsih, S., \& Setyabudi, I. (2012). Tipe Kepribadian Dan Prokrastinasi Akademik Pada Siswa Sma " X" Tangerang. Jurnal Psikologi Edukasi, 10(1), 48-57. 